\title{
Identification of ferredoxin II as a major calcium binding protein in the nitrogen-fixing symbiotic bacterium Mesorhizobium loti
}

Roberto Moscatiello ${ }^{1}$, Mattia Zaccarin ${ }^{2}$, Flavia Ercolin ${ }^{1}$, Ernesto Damiani ${ }^{3}$, Andrea Squartini $^{4}$, Antonella Roveri $^{2}$ and Lorella Navazio ${ }^{1 *}$

\begin{abstract}
Background: Legumes establish with rhizobial bacteria a nitrogen-fixing symbiosis which is of the utmost importance for both plant nutrition and a sustainable agriculture. Calcium is known to act as a key intracellular messenger in the perception of symbiotic signals by both the host plant and the microbial partner. Regulation of intracellular free $\mathrm{Ca}^{2+}$ concentration, which is a fundamental prerequisite for any $\mathrm{Ca}^{2+}$-based signalling system, is accomplished by complex mechanisms including $\mathrm{Ca}^{2+}$ binding proteins acting as $\mathrm{Ca}^{2+}$ buffers. In this work we investigated the occurrence of $\mathrm{Ca}^{2+}$ binding proteins in Mesorhizobium loti, the specific symbiotic partner of the model legume Lotus japonicus.

Results: A soluble, low molecular weight protein was found to share several biochemical features with the eukaryotic $\mathrm{Ca}^{2+}$-binding proteins calsequestrin and calreticulin, such as Stains-all blue staining on SDS-PAGE, an acidic isoelectric point and a $\mathrm{Ca}^{2+}$-dependent shift of electrophoretic mobility. The protein was purified to homogeneity by an ammonium sulfate precipitation procedure followed by anion-exchange chromatography on DEAE-Cellulose and electroendosmotic preparative electrophoresis. The $\mathrm{Ca}^{2+}$ binding ability of the $\mathrm{M}$. loti protein was demonstrated by ${ }^{45} \mathrm{Ca}^{2+}$-overlay assays. ESI-Q-TOF MS/MS analyses of the peptides generated after digestion with either trypsin or endoproteinase AspN identified the rhizobial protein as ferredoxin II and confirmed the presence of $\mathrm{Ca}^{2+}$ adducts.

Conclusions: The present data indicate that ferredoxin II is a major $\mathrm{Ca}^{2+}$ binding protein in M. loti that may participate in $\mathrm{Ca}^{2+}$ homeostasis and suggest an evolutionarily ancient origin for protein-based $\mathrm{Ca}^{2+}$ regulatory systems.
\end{abstract}

Keywords: Calcium binding proteins, Calcium homeostasis, Ferredoxin II, Mesorhizobium loti, Nitrogen fixation, Rhizobium-legume symbiosis

\section{Background}

Rhizobia are Gram-negative soil bacteria, which establish in the rhizosphere an intimate mutualistic interaction with leguminous plants. During this symbiosis, in which new organs called nodules are de novo generated on plant roots, the microsymbiont provides the plant with fixed nitrogen, receiving in turn fixed carbon from the host [1]. Nitrogen-fixing symbiosis is one of the most important beneficial plant-microbe interactions, supplying dozens of million tons of reduced nitrogen every year to agricultural systems [2]. The rhizobial bacterium

\footnotetext{
*Correspondence: Iorella.navazio@unipd.it

'Department of Biology, University of Padova, Via U. Bassi 58/B, 35131

Padova, Italy

Full list of author information is available at the end of the article
}

Mesorhizobium loti and the leguminous plant Lotus japonicus, whose genomes have been sequenced [3,4], are widely used as model organisms in the study of rhizobium-legume symbiosis [5]. In the last decade a great deal of scientific attention has been focused on the biochemical dialogue that is progressively established in the rhizosphere, based on the reciprocal exchange of diffusible signals between the two symbiotic partners in the soil. In particular, the role of calcium as critical intracellular messenger involved in the perception and transduction of symbiotic signalling molecules has become increasingly apparent. $\mathrm{A} \mathrm{Ca}^{2+}$-mediated symbiotic signalling pathway has been shown to be activated by symbiosis-related signals not only in the host plant [6], but also in the rhizobial partner [7-10]. Measurements 
of intracellular $\mathrm{Ca}^{2+}$ concentration by means of recombinant aequorin expression demonstrated a tight regulation of cytosolic $\mathrm{Ca}^{2+}$ level in $M$. loti and the occurrence of $\mathrm{Ca}^{2+}$-based mechanisms to detect changes in the soil environment [7].

A fine-tuned $\mathrm{Ca}^{2+}$ homeostatic machinery underlies the use of $\mathrm{Ca}^{2+}$ as intracellular messenger for signal transduction in any biological systems, either eukaryotic or bacterial $[11,12]$. The complex $\mathrm{Ca}^{2+}$ homeostasis toolkit of eukaryotic cells is made of several membranelocated active $\mathrm{Ca}^{2+}$ transporters $\left(\mathrm{Ca}^{2+}\right.$ pumps and/or $\mathrm{Ca}^{2+}$ exchangers), that mediate the efflux of the ion into the extracellular milieau or its sequestration into different intracellular $\mathrm{Ca}^{2+}$ stores [13]. Several intracellular compartments are equipped with a variety of soluble $\mathrm{Ca}^{2+}$ buffering proteins, able to bind $\mathrm{Ca}^{2+}$ with different affinities and capacities [14]. Recent evidence indicates that $\mathrm{Ca}^{2+}$ buffers are likely to play a critical role in $\mathrm{Ca}^{2+}$ homeostasis also in bacteria. In the cyanobacterium Anabaena sp., the $\mathrm{Ca}^{2+}$-binding protein $\mathrm{CcbP}$ has been shown to be involved in the regulation of intracellular free $\mathrm{Ca}^{2+}$ concentration during heterocyst differentiation $[15,16]$. Based on nuclear magnetic resonance spectroscopy analysis of the structures of $\mathrm{Ca}^{2+}$-free and $\mathrm{Ca}^{2+}$-bound $\mathrm{CcbP}$ forms, it has been proposed that CcbP may represent a novel class of $\mathrm{Ca}^{2+}$-binding proteins, involved in the cytosolic sequestration of the ion in Anabaena sp. [17].

In this work, we investigated the possible occurrence of $\mathrm{Ca}^{2+}$ binding proteins as a component of the $\mathrm{Ca}^{2+}$ homeostatic machinery of the nitrogen-fixing bacterium $M$. loti. Herewith we provide evidence for the presence of a small soluble acidic protein, identified by Q-TOF MS/MS analyses as ferredoxin II that, on the basis of its biochemical features, may act as a major $\mathrm{Ca}^{2+}$ buffer in this rhizobial species.

\section{Results}

Isolation and biochemical characterization of $\mathrm{Ca}^{2+}$ buffering proteins in Mesorhizobium loti

As a first step in the search for a proteinaceous $\mathrm{Ca}^{2+}$-buffering system in $M$. loti, we considered the possibility that rhizobia might express proteins sharing a certain degree of amino acid sequence homology with the $\mathrm{Ca}^{2+}$-binding protein $\mathrm{CcbP}$ of the cyanobacterium Anabaena, which has been shown to regulate the bacterial intracellular free $\mathrm{Ca}^{2+}$ concentration during heterocyst differentiation [15-17]. Bioinformatic searches into the complete genome of $M$. loti [3] did not highlight any gene sharing a significant degree of nucleotide sequence identity with the Anabaena CcbP-encoding gene (GenBank accession no. AY919604). As a consequence, a biochemical approach was undertaken to search $\mathrm{Ca}^{2+}$-binding proteins potentially acting as $\mathrm{Ca}^{2+}$ buffers in M. loti.
Crude protein extracts were prepared from midexponential phase cultures of M. loti strain $3147^{\mathrm{T}}$ and fractionated into a soluble fraction and a membrane fraction. To isolate soluble $\mathrm{Ca}^{2+}$ buffering proteins, a selective ammonium sulfate precipitation procedure, followed by anion exchange chromatography on DEAECellulose, was applied. This experimental procedure has been traditionally used for the purification of acidic $\mathrm{Ca}^{2+}$-binding proteins, such as calsequestrin [18] and calreticulin from both animal [19] and plant [20] tissues. The same procedure has been later adopted for the isolation of the acidic $\mathrm{Ca}^{2+}$-binding protein $\mathrm{CcbP}$ from of the cyanobacterium Anabaena [15]. After separation on SDS-PAGE of protein samples, the slab gels were incubated with the cationic carbocyanine dye Stains-all, that is commonly used for the preliminary detection of acidic $\mathrm{Ca}^{2+}$-binding proteins [21]. As shown in Figure 1, a $M$. loti protein with an apparent molecular mass of about $20 \mathrm{kDa}$ stained blue with Stains-all, whereas most other proteins stained pink. As a positive control, calsequestrin, purified from rabbit skeletal muscle, was used (Figure 1). The soluble M. loti Stains-all blue-staining protein was eluted from the

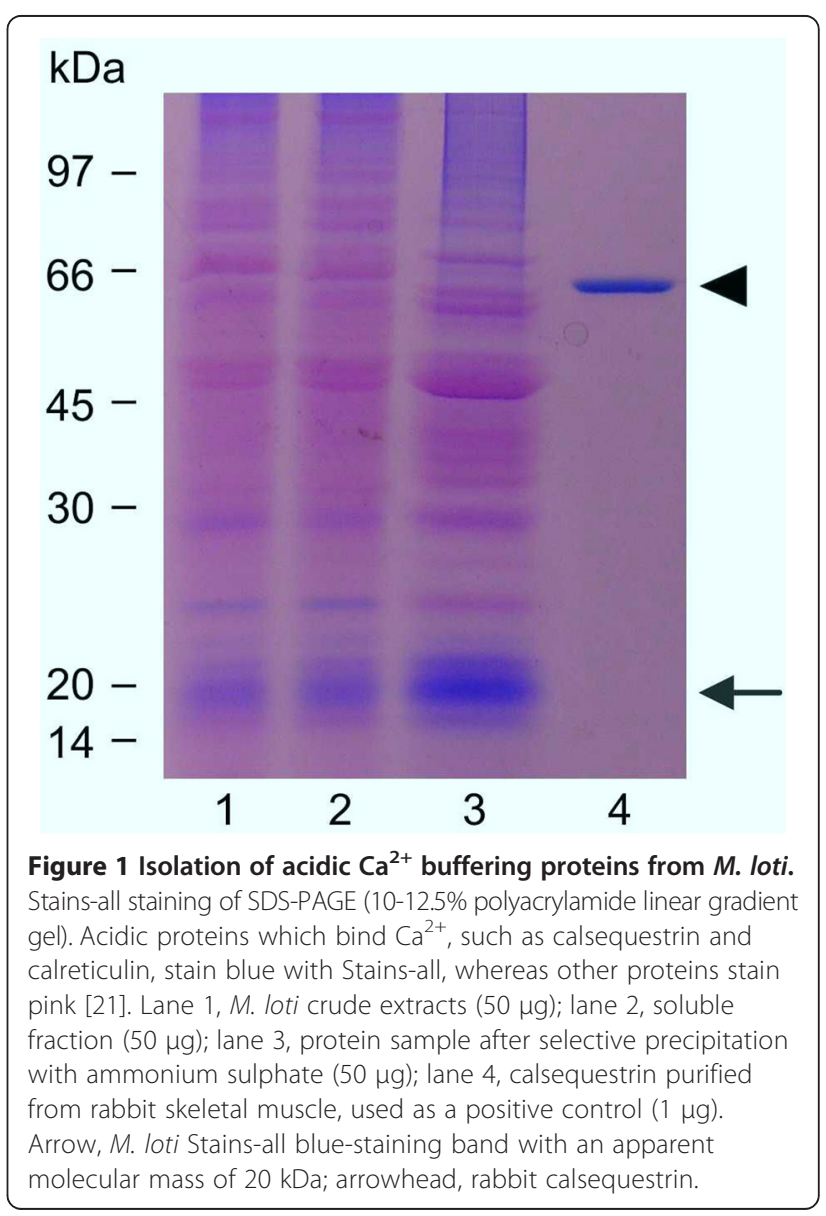


DEAE-Cellulose column at $0.45-0.55 \mathrm{M} \mathrm{NaCl}$, showing a several-fold level of enrichment (Additional file 1).

It has to be noted that Stains-all blue-staining cannot be considered as necessarily diagnostic for acidic $\mathrm{Ca}^{2+}$-binding proteins, since this dye metachromatically stains also phosphorylated proteins as well as sialoglycoproteins [22,23]. Therefore, the potential ability of the $M$. loti protein to bind $\mathrm{Ca}^{2+}$ was further investigated by a $\mathrm{Ca}^{2+}$-dependent electrophoretic mobility shift assay [24]. To this aim, $M$. loti proteins partially purified by DEAE-Cellulose were electrophoresed on SDS-PAGE containing either EGTA or $\mathrm{CaCl}_{2}$. As shown in Figure 2, the major M. loti Stains-all bluestaining band of about $20 \mathrm{kDa}$ shifted to a lower apparent $\mathrm{M}_{\mathrm{r}}$ in the presence of $\mathrm{Ca}^{2+}$, like rabbit calsequestrin did.

Since eukaryotic high-capacity, low-affinity $\mathrm{Ca}^{2+}$ binding proteins such as calsequestrin and calreticulin are characterized by an acidic isoelectric point [25], isoelectric focusing (IEF) analyses of the $M$. loti putative $\mathrm{Ca}^{2+}$-binding protein were carried out. The M. loti Stains-all blue-staining protein band was indeed found to migrate in the low $\mathrm{pH}$ region of the gel (Figure 3 ) and, when analysed by liquid phase IEF, exhibited a pI of 4.2 (data not shown).

To further purify the protein to homogeneity, electroendosmotic preparative electrophoresis (EPE) was performed, yielding a fraction containing the virtually pure $20 \mathrm{kDa}$ M. loti protein (fraction 8 in Additional file 2). The $\mathrm{Ca}^{2+}$ binding ability of the purified protein was confirmed by ${ }^{45} \mathrm{Ca}^{2+}$ overlay assays, in which calsequestrin and cytochrome $\mathrm{c}$ were used as positive and negative controls, respectively (Figure 4).

\section{Identification of the $\mathrm{M}$. loti $\mathrm{Ca}^{2+}$ binding protein by mass spectrometry}

Mass spectrometry (MS) analyses, carried out after digestion with either trypsin or endoproteinase AspN, identified the protein purified from EPE as ferredoxin II. Best coverage and identification results were then obtained from fraction 8, while some ferredoxin II peptides were identified below significance threshold also in fraction 7 and 9 (data not shown). This is probably due to different abundance of the protein in each fraction or to uncovered post-translational modifications of its residues in fraction 7 and 9. Overall sequence coverage of $54 \%$ was reached among trypsin and AspN digestion, thus confirming the presence of ferredoxin II in fraction 8 (Figure 5). With reference to the RhizoBase at Kazusa Genome Resources, there are five ferredoxins (msl0793, mll5100, mlr5869, mlr5930, msl8750) plus a ferredoxin-like protein (msl5859) and a probable ferredoxin (msr9193) in Mesorhizobium loti with low sequence homology to the one identified by our analyses (mlr3855). Moreover, we retrieved sequences from at least other three ferredoxins spanning high sequence homology to identified mlr3855 in Rhizobium leguminosarum, Sinorhizobium meliloti and Bradyrhizobium japonicum, thus supporting a relevant role for this protein in nitrogen-fixing bacteria (Figure 6). In silico sequence analysis with ScanProsite tool [26] (http:// prosite.expasy.org/scanprosite/) confirmed the presence of two $4 \mathrm{Fe}-4 \mathrm{~S}$ ferredoxin-type iron-sulfur binding domain

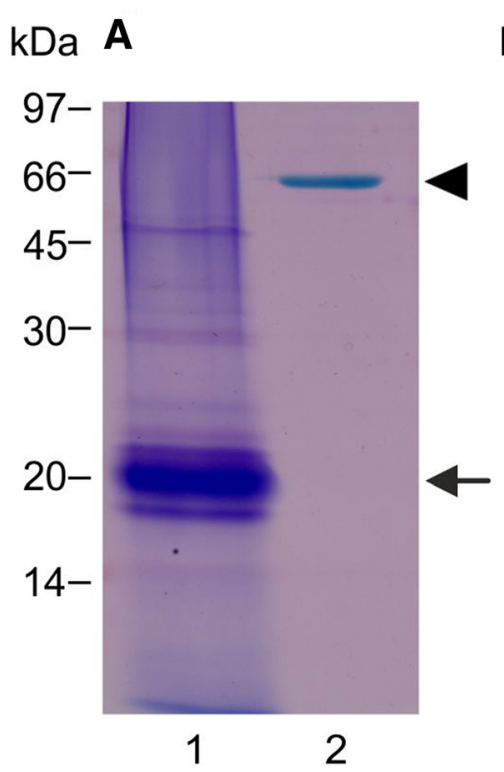

\section{$\mathrm{kDa} B$}

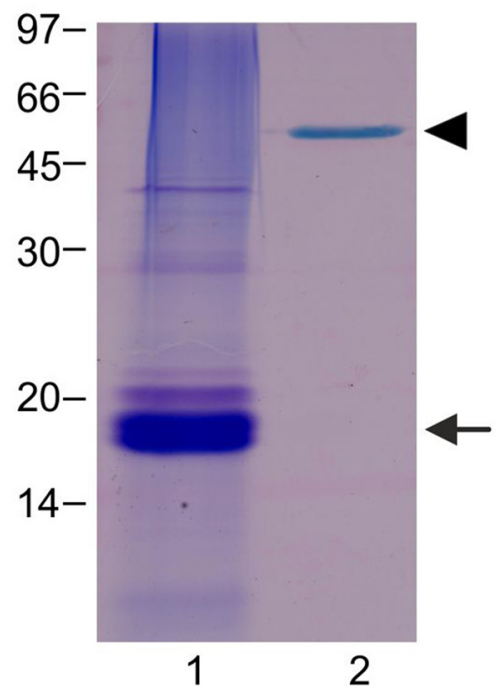

Figure $2 \mathrm{Ca}^{2+}$-dependent changes of electrophoretic mobility. Proteins were electrophoresed on 12.5\% SDS-PAGE either in the presence of $1 \mathrm{mM}$ EGTA (A) or $1 \mathrm{mM} \mathrm{CaCl}_{2}$ (B) and stained with Stains-all. Lane 1, $20 \mathrm{kDa}$ M. loti protein partially purified by DEAE-Cellulose (2 $\mu \mathrm{g}$, arrow); lane 2 , rabbit calsequestrin, used as positive control $(0.5 \mu \mathrm{g}$, arrowhead). 


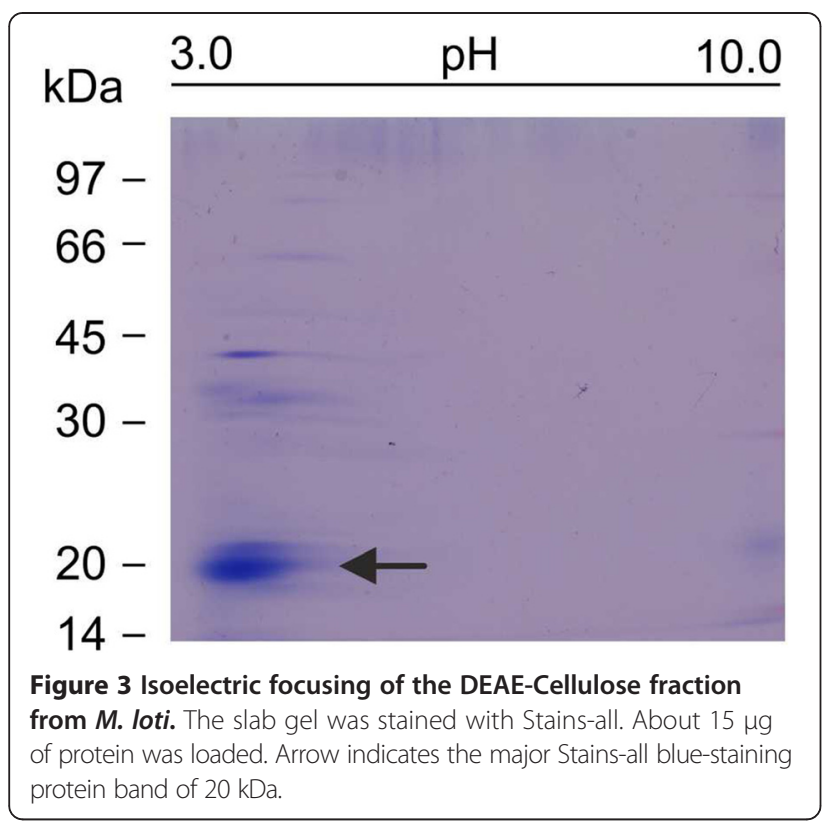

profiles between residues 1-30 and 31-60 in the cysteinerich region of mlr3855, which we partially covered by MS analysis.

Interestingly, the doubly charged tryptic fragment YFSAEPGEGD (m/z 536.2123) was also identified in a form modified by an adduct with $\mathrm{Ca}^{2+}$ (m/z 555.1855) (Additional file 3), further strengthening the notion that the $M$. loti protein is indeed a $\mathrm{Ca}^{2+}$-binding protein.

The protein has a predicted molecular mass of 12553.13 $\mathrm{Da}$ and a theoretical pI of 4.18, in perfect agreement with the value (4.2) identified by IEF analyses. The discrepancy between the actual molecular mass and the apparent molecular weight on SDS-PAGE (Figures 1, $2,3)$ is a common feature of acidic $\mathrm{Ca}^{2+}$ binding proteins, which often migrate anomalously in Laemmli SDS-PAGE [25].

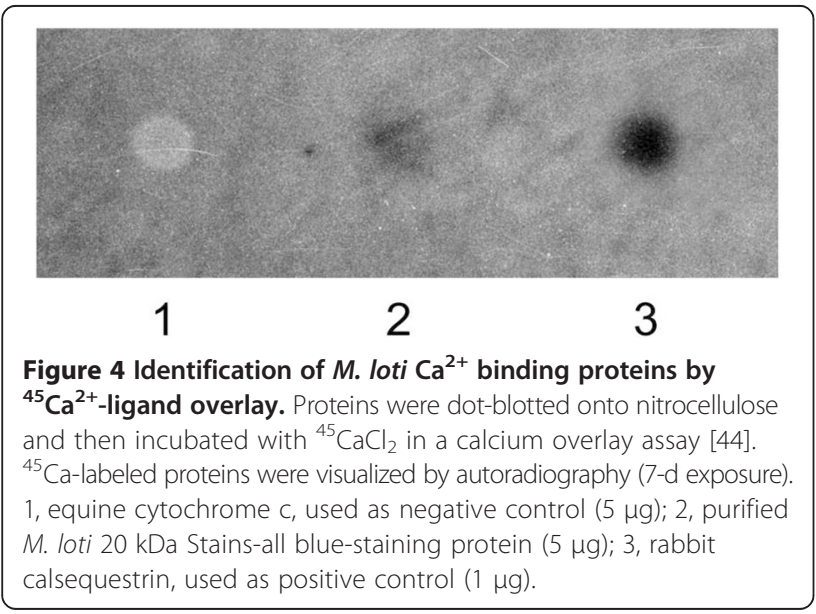

\section{Discussion}

In this work we have provided evidence for the occurrence of a major soluble $\mathrm{Ca}^{2+}$ binding protein in the nitrogen-fixing bacterium $M$. loti USDA $3147^{\mathrm{T}}$ strain. This small acidic protein, which was isolated by using an experimental procedure commonly adopted for the extraction and purification of calsequestrin and calreticulin from animal tissue homogenates, was identified as ferredoxin II by tandem mass spectrometry analyses with an ESI-Q-TOF instrument. Ferredoxin II shares with eukaryotic $\mathrm{Ca}^{2+}$ buffering proteins several biochemical features, i.e. metachromatic staining with Stains-all, an acidic isoelectric point, the $\mathrm{Ca}^{2+}$-dependent change of electrophoretic mobility and the $\mathrm{Ca}^{2+}$-binding ability in ${ }^{45} \mathrm{Ca}^{2+}$ overlay assay. All these characteristics, together with mass spectrometry evidence for a $\mathrm{Ca}^{2+}$ adduct in the C-terminal region peptide YFSAEPGEGD, suggest that ferredoxin II may participate in $\mathrm{Ca}^{2+}$ homeostasis in M. loti.

Further investigations are needed to unravel the physical basis for ferredoxin II ability to bind $\mathrm{Ca}^{2+}$, since the protein lacks classical EF-hand motifs. However, it is possible to speculate that the abundance of negatively charged amino acid residues present in the $\mathrm{C}$-terminal region of the protein, where aspartic and glutamic acid residues reach $40 \%$ of the sequence along the last ten residues, may play some role, as hypothesized for CP12, a novel $\mathrm{Ca}^{2+}$-binding protein which has recently been identified in the chloroplasts of Arabidopsis thaliana [27]. Moreover, based on the class assignment for solvent accessibility of the tool NetSurfP - Protein Surface Accessibility and Secondary Structure Prediction (Technical University of Denmark, http://www.cbs.dtu.dk/services/ NetSurfP/), the last eight residues encompassing two glutamic and one aspartic acid are exposed to solvent in mlr3855, thus they are possibly accessible to $\mathrm{Ca}^{2+}$ and prone to formation of adducts, like the one confirmed here by MS/MS data.

$\mathrm{Ca}^{2+}$ is acknowledged as a ubiquitous and versatile intracellular messenger, able to transduce a wide variety of signals into proper cellular responses in all eukaryotic cells $[13,28,29]$. Increasing evidence suggest that the basic components of $\mathrm{Ca}^{2+}$ homeostasis and signalling machineries are present in bacteria as well [30-32]. In rhizobium-legume symbiosis, $\mathrm{Ca}^{2+}$ has been demonstrated to be involved in the perception of symbiotic signals not only by the plant host [33] but also by the bacterial partner. In particular, several plant-derived diffusible molecules, such as tetronic acid in M. loti [7] and the flavonoid naringenin in $R$. leguminosarum $[8,10]$ were found to trigger transient intracellular $\mathrm{Ca}^{2+}$ changes leading to the expression of bacterial nodulation genes. Although the molecular identity of the $\mathrm{Ca}^{2+}$-permeable channels involved in the observed $\mathrm{Ca}^{2+}$ fluxes 
1 MTYVVTDNCI KCKYMDCIEV CPVDCFYEGE NMLVIMPDEC IDCGVCEPEC

51 PADAIKPDTE PGLDKWLQIN TEYAEKWPNI TAKKEPPADA KTFDGEAGKF

101 EKYFSAEEPGE GD

Identified peptides table:

\begin{tabular}{|c|c|c|c|c|c|c|c|}
\hline $\begin{array}{c}\text { Observed } \\
\text { Mass }\end{array}$ & $\begin{array}{c}\text { MW } \\
\text { expected }\end{array}$ & $\begin{array}{c}\text { MW } \\
\text { calculated }\end{array}$ & $\begin{array}{l}\text { Error } \\
\text { (ppm) }\end{array}$ & $\begin{array}{c}\text { Missed } \\
\text { cleavages }\end{array}$ & $\begin{array}{c}\text { Mascot } \\
\text { Score }\end{array}$ & Sequence & Protease \\
\hline 415.2308 & 828.447 & 828.4494 & -2.87 & 0 & 28 & K.WPNITAK.K & Trypsin \\
\hline 285.822 & 854.4441 & 854.4498 & -6.6 & 1 & 41 & K.KEPPADAK.T & Trypsin \\
\hline 536.2123 & 1070.41 & 1070.4193 & -8.63 & 0 & 31 & K.YFSAEPGEGD.- & Trypsin \\
\hline 697.8482 & 1393.6818 & 1393.6877 & -4.27 & 0 & 35 & K.WLQINTEYAEK.W & Trypsin \\
\hline 578.2984 & 1154.5822 & 1154.5819 & 0.3 & 1 & 40 & A.DAIKPDTEPGL.D & AspN \\
\hline 861.8037 & 1721.5929 & 1721.6041 & -6.55 & 1 & 33 & P.DEC $C^{1} I D C^{1} G V C^{2} E^{2} E C^{2}$ PA.D & AspN \\
\hline 933.8538 & 1865.693 & 1865.694 & -0.55 & 1 & 43 & P.DEC ${ }^{1}$ IDC $^{1} \mathrm{GVC}^{1} \mathrm{EPEC}^{1}$ PA.D & AspN \\
\hline 678.2975 & 2031.8707 & 2031.8698 & 0.48 & 1 & 16 & F.DGEAGKFEKYFSAEPGEGD.- & AspN \\
\hline
\end{tabular}

${ }^{1}$ Cysteine residue modified with acrylamide adduct $(+71.037114)$

${ }^{2}$ Half of a disulfide bridge $(-1.007825)$

Figure 5 One letter code amino acid sequence of ferredoxin II (mlr3855) from Mesorhizobium loti strain MAFF303099. Peptides identified by MS analysis are colored in red.

remains elusive, in this work another essential component of the $\mathrm{Ca}^{2+}$ homeostatic machinery, i.e. a protein $\mathrm{Ca}^{2+}$ buffer, was identified. It has recently been hypothesized that $\mathrm{Ca}^{2+}$ buffering proteins, in addition to quickly bind and thus remove free $\mathrm{Ca}^{2+}$ ions that can have toxic effect for the cell, can also play a crucial role in shaping the $\mathrm{Ca}^{2+}$ signals [34].

In the cyanobacterium Anabaena sp. strain PCC 7120 the $\mathrm{Ca}^{2+}$-binding protein $\mathrm{CcbP}$ was found to play an important role in the regulation of intracellular free $\mathrm{Ca}^{2+}$ concentration during heterocyst differentiation [15]. In particular, the protein was found to be degraded by the serine-type protease $\mathrm{HetR}$, thereby releasing bound $\mathrm{Ca}^{2+}$ and significantly contributing to the establishment of higher levels of cytosolic $\mathrm{Ca}^{2+}$ in mature heterocysts [16].

In a recent comparative proteomic analysis of $M$. loti MAFF303099, no change in the expression of ferredoxin II was found between the free-living and symbiotic condition [35], in agreement with previous results obtained by transcriptomic analysis [36]. Similarly, a putative ferredoxin II encoding gene (RL4616) in R. leguminosarum bv. viciae was not among the significantly upregulated genes in bacteroids compared with free-living cells [37]. These data suggest that ferredoxin II may play an essential constitutive function in rhizobia as a part of the bacterial $\mathrm{Ca}^{2+}$ homeostat. It remains to be established whether the transition from free-living bacteria to bacteroids may involve changes in intracellular free $\mathrm{Ca}^{2+}$ concentration in $M$. loti, thereby possibly involving a post-translational regulatory mechanism for the level of ferredoxin II, similar to that described for cyanobacterial CcbP.

It cannot be ruled out that $M$. loti ferredoxin II may play additional roles within the rhizobial cell. Based on the Rhizobase at Kazusa DNA Research Institute, M. loti ferredoxin II falls within the functional category of central intermediary metabolism and nitrogen metabolism [35]. Interestingly, a protein sharing a significantly high homology (83\%) with M. loti ferredoxin II is found also in Rhodopseudomonas palustris, a metabolically versatile photosynthetic bacterium able to fix nitrogen. A relevant similarity between genes of rhizobia and Rhodopseudomonas is not unexpected as they share a close terminal branch in 16S rRNA phylogeny [38], which entails

\begin{tabular}{|c|c|}
\hline $\begin{array}{l}\text { RL } 4616 \\
\text { SMc03875 } \\
\text { mlr3855 } \\
\text { bl10157 }\end{array}$ & 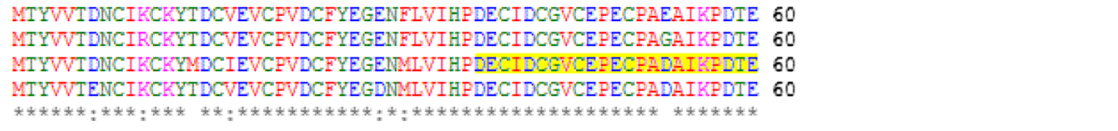 \\
\hline $\begin{array}{l}\text { RL } 4616 \\
\text { SMc03875 } \\
\text { mlr3855 } \\
\text { bl10157 }\end{array}$ & 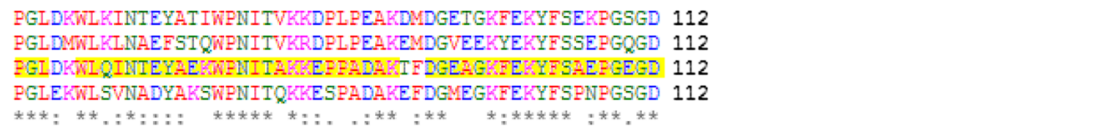 \\
\hline \multicolumn{2}{|c|}{$\begin{array}{l}\text { Figure } 6 \text { Alignment of ferredoxin sequences from different rhizobial species. Ferredoxin II (mlr3855) from M. loti MAFF303099 showed 85\% } \\
\text { amino acid sequence identity with a putative ferredoxin II (RL4616) from Rhizobium leguminosarum bv. viciae 3841, 75\% with a putative ferredoxin } \\
\text { protein from Sinorhizobium meliloti } 1021 \text { (SMc03875) and 83\% with ferredoxin (bll0157) from Bradyrhizobium japonicum USDA110. mlr3855 sequence } \\
\text { covered by MS analysis is highlighted in yellow. }\end{array}$} \\
\hline
\end{tabular}


recent separation and consequently high colinearity of their genomes.

Indeed, a commonality among eukaryotic organellar $\mathrm{Ca}^{2+}$ buffering proteins is to be multifunctional proteins, carrying out additional important functions not necessarily directly related to $\mathrm{Ca}^{2+}$ homeostasis [14]. In particular, the presence of $\mathrm{Fe}-\mathrm{S}$ clusters renders ferredoxin II particularly suited for electron transfer during redox reactions, similarly to ferredoxin. Interestingly, $\mathrm{Ca}^{2+}$ binding to a plant ferredoxin has been hypothesized to affect both the buffering capacity of the chloroplast stroma and the formation of complexes with ferredoxindependent oxidoreductases [39].

Our findings support the notion that proteins with the ability to bind $\mathrm{Ca}^{2+}$ appeared early in the history of life, possibly contributing to the regulation of intracellular free $\mathrm{Ca}^{2+}$ levels and to the consequent evolution of $\mathrm{Ca}^{2+}$-based signalling mechanisms [12].

\section{Conclusions}

In this work we demonstrated that ferredoxin II is a major $\mathrm{Ca}^{2+}$ binding protein in $M$. loti, potentially acting as a primitive system to control intracellular free $\mathrm{Ca}^{2+}$ concentration in this rhizobial species. The elucidation of the mechanisms involved in $\mathrm{Ca}^{2+}$ homeostasis in rhizobia may help to better understand the $\mathrm{Ca}^{2+}$ signalling events underlying the early stages of nitrogen-fixing symbiosis with host legumes.

\section{Methods}

\section{Strain and growth conditions}

M. loti USDA strain $3147^{\mathrm{T}}$, kindly provided by P. Van Berkum (USDA, Beltsville MD), was cultured in minimal BIII medium [40] at $28^{\circ} \mathrm{C}$, as previously described [7]. For protein sample preparations, cells were harvested at $\mathrm{OD}_{600 \mathrm{~nm}}=0.6$ (mid-growth phase).

\section{Isolation and purification of acidic $\mathrm{Ca}^{2+}$ binding proteins}

To prepare protein crude extracts from M. loti suspension cell cultures, cells were harvested by centrifugation at $3000 \mathrm{~g}$ for $20 \mathrm{~min}$ at $4^{\circ} \mathrm{C}$, washed twice with fresh medium, centrifuged again and resuspended in 4 volumes of phosphate-buffered saline (PBS) supplemented with $0.5 \mathrm{mM}$ benzamidine and $0.5 \mathrm{mM}$ phenylmethylsulfonyl fluoride. Bacteria were lysed by 3 cycles of $30 \mathrm{~s}$ each of sonication at $35 \mathrm{~Hz}$ (Fisher Sonic, Artek Farmingdale, NY, USA), each followed by $30 \mathrm{~s}$ on ice. After sonication, samples were centrifuged at $1600 \mathrm{~g}$ for $15 \mathrm{~min}$ at $4^{\circ} \mathrm{C}$ to pellet down and discard non lysed bacteria.

Total protein extracts (from about $25 \mathrm{~g}$ cells, fresh weight) were further fractionated in a soluble and membrane fractions by centrifugation at $150.000 \mathrm{~g}$ for $45 \mathrm{~min}$ at $4^{\circ} \mathrm{C}$ : the supernatant, containing soluble proteins, was subjected to a selective ammonium sulfate precipitation procedure followed by DEAE-Cellulose column chromatography, as described by Slupsky et al. [18]. Protein fractions from the DEAE-Cellulose column (DE52, Whatman, Maidstone, UK) collected between 0.4 and $0.5 \mathrm{M} \mathrm{NaCl}$ were further purified by using electroendosmotic preparative electrophoresis (EPE) [41], which was carried out with an ELFE apparatus (Genenco Life Science, M-Medical srl, Firenze, Italy). Protein concentration was determined by using the Bio-Rad Protein Assay (Bio-Rad Laboratories, Hercules, CA, USA), according to manufacturer's instructions.

In some experiments calsequestrin, purified from rabbit skeletal muscle as previously described [42] was used as positive control.

\section{Gel electrophoresis analyses}

One-dimensional SDS-PAGE was performed according to Laemmli [43], using 10 to $12.5 \%$ polyacrylamide linear gradient gels or $12.5 \%$ gels. $\mathrm{Ca}^{2+}$-dependent electrophoretic mobility shift assays were performed by separating protein samples on SDS-PAGE slab gels containing either $1 \mathrm{mM}$ EGTA or $1 \mathrm{mM} \mathrm{CaCl}_{2}$, both in the stacking and in the separating gels [24].

For in gel-isoelectric focusing (IEF), purified M. loti proteins were thoroughly desalted and resuspended in $0.2 \mathrm{ml}$ of $9 \mathrm{M}$ urea, $2 \mathrm{M}$ thiourea, 4\% (w/v) 3-[(3-cholamidopropyl) dimethylammonio]-1-propanesulfonate (CHAPS) and $2 \mathrm{mM}$ tris(2-carboxyethyl)phosphine (TCEP) using Micro Bio-Spin columns (Bio-Rad). Ampholytes, 3-10 pH range (Bio-Rad), and bromophenol blue were then added to the sample at $0.2 \%$ and $0.01 \%(\mathrm{w} / \mathrm{v})$ final concentration, respectively. Isoelectric focusing (IEF) was performed on $11 \mathrm{~cm}$ IEF strips, 3-10 pH range (Bio-Rad). When $7 \mathrm{~cm}$ IEF strips, pH range 4-7 (Bio-Rad), were used, the separation was performed on $0.125 \mathrm{ml}$ sample, in the presence of ampholytes, 4-7 $\mathrm{pH}$ range (Bio- $\mathrm{Rad}),(0.2 \%, \mathrm{w} / \mathrm{v})$, for $10,000 \mathrm{~V} / \mathrm{h}$. Before the second dimension separation on a $10-12.5 \%$ gradient SDS-PAGE, the strips were equilibrated in $10 \mathrm{ml}$ of $0.375 \mathrm{M}$ tris- $\mathrm{HCl}, \mathrm{pH} 8.8$ containing $2 \%(\mathrm{w} / \mathrm{v})$ SDS, $6 \mathrm{M}$ urea, 20\% (v/v) glycerol and $2 \%$ DTT for 10 minutes and then in the same buffer with $2.5 \%(\mathrm{w} / \mathrm{v})$ iodoacetamide.

Liquid-phase IEF was instead performed by using a MicroRotofor Cell (Bio-Rad). In this case M. loti proteins were thoroughly desalted on NAP 5 columns (GE Healthcare, Little Chalfont, Buckinghamshire, UK) and resuspended in $2.5 \mathrm{ml}$ of focusing buffer: $7 \mathrm{M}$ urea, $2 \mathrm{M}$ thiourea, 4\% (w/v) CHAPS, $2 \mathrm{mM}$ TCEP and 3\% (w/v) ampholytes, $3-10 \mathrm{pH}$ range. Proteins were separated at constant power $(1 \mathrm{~W})$ for $5 \mathrm{~h}$ using $0.1 \mathrm{M} \mathrm{H}_{3} \mathrm{PO}_{4}$ at the anode and $0.1 \mathrm{M} \mathrm{NaOH}$ at the catode. At the end of the 
run ten protein fractions of almost the same volume were collected and used for further studies.

Slab gels were stained with Coomassie Blue, completely destained and then restained with Stains-all, as described by Campbell et al. [21].

\section{${ }^{45} \mathrm{Ca}^{2+}$ overlay assay}

${ }^{45} \mathrm{Ca}^{2+}$ overlay assay was carried out by the technique described by Maruyama et al. [44]. Proteins were spotted directly onto nitrocellulose membranes. Rabbit calsequestrin was used as positive control, equine cytochrome c (Sigma-Aldrich) was used as negative control. ${ }^{45} \mathrm{CaCl}_{2}$ was purchased from Perkin-Elmer (Boston, MA, USA). ${ }^{45} \mathrm{Ca}^{2+}$-labeled proteins were visualized by autoradiography on Amersham Hyperfilm MP (GE Healthcare).

\section{Q-TOF analyses}

For Q-TOF analyses, proteins purified by the EPE technique (fractions 7-8-9 separately) were used, after buffer exchange with Vivaspin 6 concentrators with a $5000 \mathrm{MW}$ cut-off (Sartorius Stedim Biotech $\mathrm{GmbH}$, Goettingen, Germany) against $40 \mathrm{mM} \mathrm{NH} \mathrm{HCO}_{3}, 10 \%$ (v/v) acetonitrile $\mathrm{pH}$ 8.0. Each fraction was then digested either with trypsin and endoproteinase AspN based on obtainable coverage predicted in silico [45] (http://web.expasy.org/ peptide_mass/). $100 \mathrm{ng}$ of each protease were used for overnight digestion at $37^{\circ} \mathrm{C}$ and reaction was stopped by acidification with formic acid (FA) $1 \%(\mathrm{v} / \mathrm{v}$ ) final concentration. Digests were dried by vacuum centrifugation and resuspendend into a minimal volume of $0.1 \%$ FA for subsequent MS analysis. 1 to $10 \mu \mathrm{l}$ of each peptide mixture, obtained from the digestion of protein samples, were analyzed by means of reversed-phase chromatography on a nano-fluidic HPLC-Chip apparatus coupled with a quadrupole ion trap and time of flight mass spectrometer, using the 6520 Accurate-Mass Q-TOF LC/MS system (Agilent Technologies) equipped with MassHunter Workstation Software Qualitative Analysis B.02.00 as graphical interface for data handling. A 1200 Rapid Resolution system (Agilent Technologies, Santa Clara, CA, USA) containing a binary pump and degasser and a well-plate autosampler with thermostat were associated to the HPLC-Chip interface directly connected to a nanoESI ionization source. Loaded samples were thus enriched on a $160 \mathrm{nl}$ enrichment column and separated with an acetonitrile gradient on a $75 \mu \mathrm{m} \times 150 \mathrm{~mm}$ separation column packed with Zorbax 300SB-C18 $5 \mu \mathrm{m}$ material. Data dependent MS/ MS analysis were carried on the 3th most intense peaks from each MS scan using collision induced dissociation fragmentation (CID) with dynamic exclusion in order to enhance sequencing of less abundant peptides.

\section{Data analysis}

MS/MS data were extracted for identification purpose from raw data by means of MassHunter Workstation Software Qualitative Analysis and converted to Mascot generic format datafile (.mgf). Thus, data were analysed with Mascot server (ver. 2.3, Matrix Science Ltd.) being classified by a probability based implementation of the Mowse algorithm: experimental mass spectra produced were correlated to peptide sequences obtained by comparison with the theoretical mass spectra in the RhizoBase protein database downloaded from the Kazusa DNA Research Institute website (http://genome. microbedb.jp/RhizoBase). As the confidence of protein identification a precursor mass tolerance of no more than $10 \mathrm{ppm}$ and MS/MS product mass tolerance of no more than $0.05 \mathrm{Da}$ were adopted. Methionine oxidation, asparagine/glutamine deamidation and cysteine disulfide or acrylamide adducts formation were considered as routine possible post-translational modification (PTM). Sequence alignments were performed by means of ClustalW2 alignment tool (http://www.ebi.ac.uk/Tools/msa/clustalw2/) using Gonnet protein weight matrix.

\section{Accession numbers}

All MS/MS data were searched with Mascot server 2.3 against Mesorhizobium loti protein sequences downloaded from the RhizoBase database (http://genome. microbedb.jp/rhizobase/Mesorhizobium/genes.faa). Accession numbers of identified proteins refers to the ones contained in this database.

\section{Additional files}

Additional file 1: Purification of $M$. loti acidic $\mathrm{Ca}^{2+}$ buffering proteins by DEAE-Cellulose chromatography. A: Elution profile of $M$. loti proteins on DEAE-Cellulose chromatography. The column was eluted with a $50 \mathrm{mM}-1 \mathrm{M} \mathrm{NaCl}$ linear gradient, as indicated. B: Stains-all staining of 10-12.5\% SDS-PAGE. Key to lanes: L, protein mixture loaded onto the column, after selective precipitation with ammonium sulphate $(10 \mu \mathrm{g})$; V, void volume $(10 \mu \mathrm{g}) ; 1-12$, fractions eluted from the DEAE-Cellulose column (100 $\mu$ l each, containing 1-10 $\mu \mathrm{g}$ protein). The protein fraction size was $2 \mathrm{ml}$.

Additional file 2: SDS-PAGE analysis of samples obtained from the fractionation of $M$. loti proteins by electroendosmotic preparative electrophoresis. Protein fractions (fraction size: $1 \mathrm{ml}$ ) were electrophoresed on 12.5\% SDS-PAGE (18 $\mu$ l per lane) and stained with Stains-all. Only fractions 1 to 9 are shown. Molecular masses of standard proteins are indicated on the left side of the gel.

Additional file 3: YFSAEPGEGD mlr3855 peptide identification data with and without $\mathrm{Ca}^{2+}$ adduct on glutamic acid residue. A: MS/MS spectra (left) and matched MS/MS fragment masses (right) for peptide YFSAEPGEGD at $\mathrm{m} / \mathrm{z}$ 536.2123, 2+ at retention time 11.124 minutes. B: MS/MS spectra (left) and matched MS/MS fragment masses (right) for peptide YFSAEPGEGD modified with $\mathrm{Ca}^{2+}$ cation adduct on glutamic acid residue in position $\# 5$ at $\mathrm{m} / \mathrm{z} 555.1855,2+$ at retention time 11.039 minutes. $\mathrm{b}$ and $\mathrm{y}$ refers to $\mathrm{CID}$ fragmentation ionic series, $\mathrm{b} / \mathrm{y}^{0}$ are $-\mathrm{H}_{2} \mathrm{O}$ fragment ions and $\mathrm{b} / \mathrm{y}^{++}$are doubly charged fragment ions according to Mascot nomenclature (Matrix Sciences). 


\section{Competing interests}

The authors declare that they have no competing interests.

\section{Authors' contributions}

RM purified and carried out the biochemical characterization of the M. lot protein. FE participated in the isolation of the protein. MZ and AR identified the protein by MS/MS analyses and helped to draft the manuscript. LN conceived of the study, evaluated the results and wrote the manuscript. AR, $\mathrm{ED}$ and $\mathrm{AS}$ participated in the design of the experiments and in the editing of the manuscript. All authors read and approved the final manuscript.

\section{Acknowledgements}

We are grateful to P. Mariani (Padua, Italy) for fruitful discussions and critical reading of the manuscript. We thank S. Furlan (Padua, Italy) for technical assistance with electroendosmotic preparative electrophoresis. This work was supported by Progetti di Ricerca di Ateneo 2012 (prot. CPDA127210) and Ricerca Scientifica fondi quota ex-60\% (prot. 60A06-5935/13) to LN. R.M. and M.Z. are post-doctoral fellowship holders of the University of Padua.

\section{Author details}

${ }^{1}$ Department of Biology, University of Padova, Via U. Bassi 58/B, 35131 Padova, Italy. ${ }^{2}$ Department of Molecular Medicine, University of Padova, Viale G. Colombo 3, 35131 Padova, Italy. ${ }^{3}$ Department of Biomedical Sciences, University of Padova, Viale G. Colombo 3, 35131 Padova, Italy. ${ }^{4}$ Department of Agronomy, Food, Natural Resources, Animals and Environment, DAFNAE, University of Padova, Viale dell'Università 16, 35020 Legnaro, Padova, Italy.

\section{Received: 6 November 2014 Accepted: 16 January 2015}

\section{Published online: 04 February 2015}

\section{References}

1. Masson-Boivin C, Giraud E, Perret X, Batut J. Establishing nitrogen-fixing symbiosis with legumes: how many rhizobium recipes? Trends Microbiol. 2009;17:458-66.

2. Udvardi M, Poole PS. Transport and metabolism in legume-rhizobia symbioses. Annu Rev Plant Biol. 2013;64:781-805.

3. Kaneko T, Nakamura Y, Sato S, Asamizu E, Kato T, Sasamoto S, et al. Complete genome structure of the nitrogen-fixing symbiotic bacterium Mesorhizobium loti. DNA Res. 2000;7:331-8.

4. Sato S, Nakamura Y, Kaneko T, Asamizu E, Kato T, Nakao M, et al. Genome structure of the legume, Lotus japonicus. DNA Res. 2008;15:227-39.

5. Saeki K, Kouchi H. The Lotus symbiont, Mesorhizobium loti: molecular genetic techniques and application. J Plant Res. 2000;113:457-65.

6. Oldroyd GE. Speak, friend, and enter: signalling systems that promote beneficial symbiotic associations in plants. Nat Rev Microbiol. 2013;11:252-63.

7. Moscatiello R, Alberghini S, Squartini A, Mariani P, Navazio L. Evidence for calcium-mediated perception of plant symbiotic signals in aequorinexpressing Mesorhizobium loti. BMC Microbiol. 2009;9:206.

8. Moscatiello R, Squartini A, Mariani P, Navazio L. Flavonoid-induced calcium signalling in Rhizobium leguminosarum bv. viciae. New Phytol. 2010;188:814-23.

9. Moscatiello R, Baldan B, Squartini A, Mariani P, Navazio L. Oligogalacturonides: novel signaling molecules in rhizobium-legume communications. Mol Plant Microbe Interact. 2012;25:1387-95.

10. Arrigoni G, Tolin S, Moscatiello R, Masi A, Navazio L, Squartini A. Calciumdependent regulation of genes for plant nodulation in Rhizobium leguminosarum detected by iTRAQ quantitative proteomic analysis. J Proteome Res. 2013;12:5323-30.

11. Clapham DE. Calcium signaling. Cell. 2007;131:1047-58.

12. Case RM, Eisner D, Gurney A, Jones O, Muallem S, Verkhatski A. Evolution of calcium homeostasis: from birth of the first cell to an omnipresent signalling system. Cell Calcium. 2007:42:345-50.

13. Berridge MJ, Lipp P, Bootman MD. The versatility and universality of calcium signalling. Nat Rev Mol Cell Biol. 2000;1:11-21.

14. Prins D, Michalak M. Organellar calcium buffers. Cold Spring Harb Perspect Biol. 2011;3:a004069.

15. Zhao Y, Yunming S, Zhao W, Huang X, Wang D, Brown N, et al. CcbP, a calcium-binding protein from Anabaena sp. PCC 7120, provides evidence that calcium ions regulate heterocyst differentiation. Proc Natl Acad Sci U S A 2005; 102:5744-8

16. Shi $Y$, Zhao W, Zhang W, Ye Z, Zhao J. Regulation of intracellular free calcium concentration during heterocyst differentiation by HetR and
NtcA in Anabaena sp. PCC 7120. Proc Natl Acad Sci U S A. 2006;103:11334-9.

17. Hu Y, Zhang X, Shi Y, Zhou Y, Zhang W, Su X-D, et al. Structures of Anabaena calcium-binding protein $\mathrm{CcbP}$ : insights into $\mathrm{Ca}^{2+}$ signaling during heterocyst differentiation. J Biol Chem. 2011;286:12381-8.

18. Slupski JR, Ohnishi M, Carpenter MR, Reithmeier RA. Characterization of cardiac calsequestrin. Biochemistry. 1987;26:6539-44.

19. Damiani E, Heilmann C, Salvatori S, Margreth A. Characterization of highcapacity low-affinity calcium binding protein of liver endoplasmic reticulum: calsequestrin-like and divergent properties. Biochem Biophys Res Commun. 1989;165:973-80.

20. Navazio L, Baldan B, Dainese $P$, James P, Damiani E, Margreth A, et al. Evidence that spinach leaves express calreticulin but not calsequestrin. Plant Physiol. 1995;109:983-90.

21. Campbell KP, MacLennan DH, Jorgensen AO. Staining of the $\mathrm{Ca}^{2+}$-binding proteins, calsequestrin, calmodulin, troponin C, and S-100, with the carbocyanine dye "Stains-all". J Biol Chem. 1983;258:11267-73.

22. Green MR, Pastewka JV, Peacock AC. Differential staining of phosphoproteins on polyacrylamide gels with a cationic carbocyanine dye. Anal Biochem. 1973;56:43-51.

23. Green MR, Pastewka JV. Identification of sialic acid-rich glycoproteins on polyacrylamide gels. Anal Biochem. 1975;65:66-72.

24. Damiani E, Margreth A. Subcellular fractionation to junctional sarcoplasmic reticulum and biochemical characterization of $170 \mathrm{kDa} \mathrm{Ca}^{2+}$ - and lowdensity-lipoprotein-binding protein in rabbit skeletal muscle. Biochem J. 1991;277:825-32

25. Milner RE, Baksh S, Shemanko C, Carpenter MR, Smillie L, Vance JA, et al. Calreticulin, and not calsequestrin, is the major calcium binding protein of smooth muscle sarcoplasmic reticulum and liver endoplasmic reticulum. J Biol Chem. 1991;266:7155-65.

26. Sigrist CJA, Cerutti L, Hulo N, Gattiker A, Falquet L, Pagni M, et al. PROSITE: a documented database using patterns and profiles as motif descriptors. Brief Bioinform. 2002;3:265-74.

27. Rocha AG, Vothknecht UC. Identification of CP12 as a novel calcium-binding protein in chloroplasts. Plants. 2013;2:530-40.

28. Dodd AN, Kudla J, Sanders D. The language of calcium signaling. Annu Rev Plant Biol. 2010;61:593-620.

29. Cai $\mathrm{X}$, Clapham DE. Ancestral $\mathrm{Ca}^{2+}$ signaling machinery in early animal and fungal evolution. Mol Biol Evol. 2012;29:91-100.

30. Michiels J, Xi C, Verhaert J, Vanderleyden J. The functions of $\mathrm{Ca}^{2+}$ in bacteria: a role for EF-hand proteins? Trends Microbiol. 2002;10:87-93.

31. Dominguez DC. Calcium signalling in bacteria. Mol Microbiol. 2004;54:291-7.

32. Dominguez DC, Guragain M, Patrauchan M. Calcium binding proteins and calcium signaling in prokaryotes. Cell Calcium, doi:10.1016/j.ceca.2014.12.006, in press

33. Oldroyd GE, Murray JD, Poole PS, Downie JA. The rules of engagement in the legume-rhizobial symbiosis. Ann Rev Genet. 2011;45:119-44.

34. Granqvist E, Wysham D, Hazledine S, Kozlowski W, Sun J, Charpentier M, et al. Buffering capacity explains signal variation in symbiotic calcium oscillations. Plant Physiol. 2012;160:2300-10.

35. Tatsukami Y, Nambu M, Morisaka H, Kuroda K, Ueda M. Disclosure of the differences of Mesorhizobium loti under the free-living and symbiotic conditions by comparative proteome analysis without bacteroid isolation. BMC Microbiol. 2013;13:180.

36. Uchiumi T, Ohwada T, Itakura M, Mitsui H, Nukui N, Dawadi $P$, et al. Expression islands clustered on the symbiosis island of the Mesorhizobium loti genome. J Bacteriol. 2004;186:2439-48.

37. Karunakaran R, Ramachandran VK, Seaman JC, East AK, Mouhsine B, Mauchline $\mathrm{TH}$, et al. Transcriptomic analysis of Rhizobium leguminosarum biovar viciae in symbiosis with host plants Pisum sativum and Vicia cracca. J Bacteriol. 2009;191:4002-14.

38. Young JP, Downer HL, Eardly BD. Phylogeny of the phototrophic rhizobium strain BTAi1 by polymerase chain reaction-based sequencing of a $16 \mathrm{~S}$ rRNA gene segment. J Bacteriol. 1991;173:2271-7.

39. Surek B, Kreimer G, Melkonian M, Latzko E. Spinach ferredoxin is a calciumbinding protein. Planta. 1987;171:565-8.

40. Dazzo FB: Leguminous root nodules. In Experimental Microbial Ecology. Edited by Burns R, Slater J. Oxford: Blackwell Scientific Publications; 1982:431-446.

41. Curioni A, Dal Belin Peruffo A, Furegon L. Electroendosmotic preparative electrophoresis: a one-step method for the purification of nearly all the proteins from complex mixtures. Basic Appl Myol. 1993;3:239-44. 
42. Damiani $E$, Volpe $P$, Margreth A. Coexpression of two isoforms of calsequestrin in rabbit slow-twitch muscle. J Muscle Res Cell Motil. 1990;11:522-30.

43. Laemmli UK. Cleavage of structural proteins during the assembly of the head of bacteriophage T4. Nature. 1970;227:680-5.

44. Maruyama K, Mikawa T, Ebashi S. Detection of calcium binding proteins by ${ }^{45} \mathrm{Ca}$ autoradiography on nitrocellulose membrane after sodium dodecyl sulfate gel electrophoresis. J Biochem. 1984:95:511-9.

45. Wilkins MR, Lindskog I, Gasteiger E, Bairoch A, Sanchez JC, Hochstrasser DF, et al. Detailed peptide characterisation using PEPTIDEMASS - a World-WideWeb-accessible tool. Electrophoresis. 1997;18:403-8.

\section{Submit your next manuscript to BioMed Central} and take full advantage of:

- Convenient online submission

- Thorough peer review

- No space constraints or color figure charges

- Immediate publication on acceptance

- Inclusion in PubMed, CAS, Scopus and Google Scholar

- Research which is freely available for redistribution 